\title{
Original Article \\ Henoch-Schonlein Purpura in Children at Department of Pediatric, Bach Mai Hospital
}

\author{
Pham Van Dem* \\ ${ }^{l}$ VNU School of Medicine and Pharmacy, Vietnam National University, Hanoi, \\ 144 Xuan Thuy, Cau Giay, Hanoi, Vietnam
}

Received 21 January 2020

Revised 25 February 2020; Accepted 20 March 2020

\begin{abstract}
Henoch-Schonlein Purpura (HSP) is one of the most common vasculitis diseases in children. HSP's main symptoms are rash, arthritis, abdominal pain and kidney disorder. This study aims to describe the epidemic characteristics and clinical manifestations of HSP in children. The study was conducted on 50 patients diagnosed with HSP at the Department of Pediatrics, Bach Mai Hospital from 2017 to 2018. The study results show that the mean age of the patients was $9.1 \pm 3.2$ years, with the ratio of male to female of 1.17:1. With seasonal characteristics, HSP is more common in the spring $(43.4 \%)$ and the winter $(26.1 \%) .44 \%$ of the HSP cases were preceded by an acute infectious or allergic illness. The common clinical manifestations were reddish-purple spots (90\%), digestive tract symptoms (68\%) and nephritis (18\%). At the end of the study period, $78 \%$ of the cases were completely recovered, $16 \%$ relapsed and $6 \%$ without remission. The study concludes that the common clinical manifestations of Henoch-Schonlein purpura are reddish-purple spots, digestive tract symptoms and high complete remission.
\end{abstract}

Keyword: Henoch-Schonlein nephritis, epidemic characteristics, clinical manifestations.

\footnotetext{
* Corresponding author.

E-mail address: phamdemhd@gmail.com

https://doi.org/10.25073/2588-1132/vnumps.4199
} 


\title{
Viêm mao mạch dị ứng ở trẻ em tại Khoa Nhi, Bệnh viện Bạch Mai
}

\author{
Phạm Văn Đếm* \\ ${ }^{1}$ Khoa Y Dược, Đại học Quốc gia Hà Nội, 144 Xuân Thủy, Cà̀u Giấy, Hà Nội, Việt Nam \\ Nhận ngày 21 tháng 01 năm 2020 \\ Chỉnh sửa ngày 25 tháng 02 năm 2020; Chấp nhận đăng ngày 20 tháng 3 năm 2020
}

\begin{abstract}
Tóm tắt: Viêm mạch dị ứng hay còn gọi là Henoch-Schonlein Purpura thường gặp ở trẻ em. Muc tiêu nghiên cúu: mô tả đặc điểm lâm sàng, cận lâm sàng của viêm mao mạch dị ứng ở trẻ em. Đối tuợng nghiên cưu: trẻ được chẩn đoán viêm mao mạch dị ứng vào điều trị tại Khoa Nhi, Bệnh viện Bạch Mai trong thời gian từ tháng 01 năm 2017 đến hết tháng 12 năm 2018. Phuoong pháp nghiên cưu: mô tả loạt ca bệnh. Kết quả: tuổi trung bình khởi phát bệnh là $9,1 \pm 3,2$ tuổi. Tỷ lệ trẻ trai/trẻ gái là 1,17:1. Tỉ lệ bệnh khởi phát vào mùa đông xuân cao nhất (38\%), $44 \%$ trường hợp có nhiễm trùng trước khi khởi phát bệnh. Triệu chứng lâm sàng gặp nhiều nhất là ban xuất huyết đối xứng 2 bên $(90 \%), 68,0 \%$ có các biểu hiện tại cơ quan tiêu hóa, $18,0 \%$ có tổn thương thận. Kết quả điều trị: $78 \%$ trẻ khỏi hoàn toàn, $16 \%$ trẻ có tái phát, không thuyên giảm là $6 \%$. Kết luận: viêm mạch dị ứng có biểu hiện chính là các ban xuất huyết đối xứng, kèm theo triệu chứng tại đường tiêu hóa, tổn thương thận ít gặp hơn, tỉ lệ điều trị khỏi cao.
\end{abstract}

Tù khóa: Viêm thận, Schonlein Henoch Purpura.

\section{1. Đặt vấn đề}

Viêm mao mạch dị ứng (VMMDU') hay còn gọi là Henoch Schonlein purpura - (HSP) là bệnh thường gặp ở trẻ em. Triệu chứng là ban xuất huyết trên da, viêm khớp, đau bụng và các biểu hiện tổn thương thận. Nhiều nghiên cứu trên thế giới đã chỉ ra rằng mức độ tổn thương thận (Henoch Schonlein purpura nephritis, HSPN) là một yếu tố tiên lượng lâu dài của bệnh. Vì vậy

\footnotetext{
* Tác giả liên hệ.

Địa chỉ email: phamdemhd@ gmail.com
}

https://doi.org/10.25073/2588-1132/vnumps.4199 tổn thương thận cần được khảo sát ở tất cả các bệnh nhân HSP [1].

Tại Việt Nam, nghiên cứu về VMMDU' nói chung chưa đầy đủ, cho đến nay, tại Khoa Nhi, Bệnh viện Bạch Mai chưa có tác giả nào nghiên cứu về bệnh này ở trẻ em. Vì vậy tôi thực hiện nghiên cứu này với hai mục tiêu sau: i) Mô tả các đặc điểm dịch tễ học lâm sàng và cận lâm sàng của VMMDU' ở trẻ em tại Khoa Nhi, Bệnh viện 
Bạch Mai; ii) Đánh giá kết quả bước đầu điều trị bệnh.

\section{2. Đối tượng phương pháp nghiên cứu}

\section{1. Đối tượng nghiên cưu}

50 trẻ được chẩn đoán VMMDU điều trị tại khoa Nhi - Bệnh viện Bạch Mai trong 2 năm từ tháng 01 năm 2017 đến tháng 12 năm 2018.

\subsection{Phưong pháp nghiên cúu}

Nghiên cứu mô tả loạt ca bệnh.

Cỡ mẫu nghiên cứu: tất cả bệnh nhân phù hợp với tiêu chuẩn chẩn đoán.

Tiêu chuẩn lựa chọn: Trẻ $\leq 15$ tuổi, được chẩn đoán VMMDU' theo tiêu chuẩn của EULAR/ PRES/ PRINTO (Ankara 2008): khi bệnh nhân có ban xuất huyết dạng chấm nốt nổi gờ trên mặt da và ít nhất 1 trong 4 triệu chứng [1]: i) Đau bụng lan tỏa; ii) Sinh thiết tổn thương da và mạch máu có lắng đọng $\mathrm{IgA}$; iii) Viêm khớp (cấp, bất kỳ khớp nào) hoặc đau khớp; iv) Tổn thương thận (hồng cầu niệu hoặc protein niệu). Tổn thương thận được định nghĩa là: Protein/creatinin niệu $>20 \mathrm{mg} / \mathrm{mmol}$ hoặc hồng cầu niệu dương tính trên $2+$ hoặc suy thận với mức lọc cầu thận (MLCT) dưới 90 $\mathrm{ml} / 1,73 \mathrm{~m} 2 /$ phút tính theo công thức Schwartz.

Tiêu chuẩn loại trừ: các bệnh nhân HSP không có tổn thương thận, bệnh nhân và gia đình bệnh nhân không đồng ý tham gia nghiên cứu.

Trẻ mắc VMMD được điều trị theo phác đồ thống nhất của Đồng thuận trong điều trị Hội Thấp học châu Âu [2].

\subsection{Xủ lý số liệu}

Số liệu xử lý bằng phần mềm SPSS 16.0.

\section{Kết quả nghiên cứu}

\section{1. Đặc điểm dịch tế học}

Tuổi mắc từ 4 đến 15 tuổi, tập trung nhiều ở trẻ từ 6 đến 8 tuổi. Tuổi trung bình bị bệnh là
$9,1 \pm 3,2$ tuổi. Kết quả phân bố về giới: trẻ trai chiếm $54 \%$ cao hơn trẻ gái $46 \%$ khác biệt không có ý nghĩa thống kê với $\mathrm{p}=0,06$.

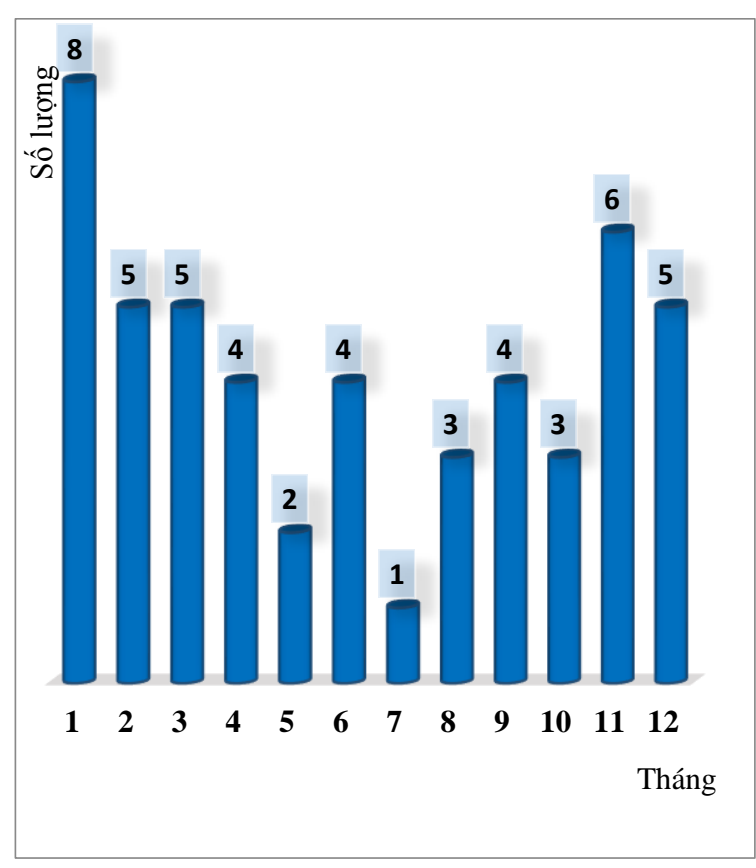

Biểu đồ 1 . Phân bố số bệnh nhân theo các tháng trong năm.

Nhận xét: thời điểm khởi phát bệnh VMMDU tập chung nhiều ở các tháng 11 đến tháng 3. Gặp nhiều nhất là vào mùa đông xuân với $38,0 \%$, mùa hè ít gặp nhất với $14,0 \%$.

Bảng 1. Các yếu tố khởi phát bệnh (n=50)

\begin{tabular}{lll}
\hline Nhiễm trùng & Số lượng & Tỷ lệ \% \\
\hline $\begin{array}{l}\text { Nhiễm trùng đường hô } \\
\text { hấp trên }\end{array}$ & 10 & 20,0 \\
$\begin{array}{l}\text { Nhiễm trùng đường hô } \\
\text { hấp dưới }\end{array}$ & 4 & 8,0 \\
Nhiềm trùng tiết niệu & 4 & 8,0 \\
Viêm dạ dày - ruột & 3 & 6,0 \\
Viêm mô tế bào da & 1 & 2,0 \\
Tổng & 22 & 44,0 \\
\hline
\end{tabular}

Nhận xét: có $44,0 \%$ bệnh nhân khởi phát bệnh có các nhiễm trùng kèm theo, và chủ yếu là nhiễm trùng đường hô hấp với $20,0 \%$. 
Bảng 2. Triệu chứng lâm sàng khi khởi phát $(\mathrm{n}=50)$

\begin{tabular}{lll}
\hline Triệu chứng & $\begin{array}{l}\text { Số } \\
\text { lượng }\end{array}$ & $\begin{array}{l}\text { Tỷ lệ } \\
\%\end{array}$ \\
\hline Ban xuất huyết ở da đơn thuần & 21 & 42,0 \\
Đau bụng đơn thuần & 9 & 18,0 \\
Sưng đau khớp đơn thuần & 3 & 6,0 \\
Ban da và đau khớp & 8 & 16,0 \\
Ban da và đau bụng & 5 & 10,0 \\
Đau khớp và đau bụng & 2 & 4,0 \\
Nôn máu & 1 & 2,0 \\
Tiểu đỏ & 1 & 2,0 \\
Tổng & 50 & 100,0 \\
\hline
\end{tabular}

Nhận xét: triệu chứng đầu tiên thường gặp là nổi ban xuất huyết ở da đơn thuần, đau bụng đơn thuần, ban xuất huyết kết hợp sưng đau khớp với tỷ lệ lần lượt là $44,0 \% ; 16,0 \% ; 16,0 \%$.

Bảng 3. Các triệu chứng lâm sàng giai đoạn toàn phát $(\mathrm{n}=50)$

\begin{tabular}{|c|c|c|c|c|c|}
\hline $\begin{array}{l}\text { Cơ } \\
\text { quan }\end{array}$ & $\mathrm{n}$ & $\%$ & $\begin{array}{l}\text { Triệu } \\
\text { chứng }\end{array}$ & $\mathrm{n}$ & $\%$ \\
\hline $\mathrm{Da}$ & 45 & 90,0 & Ban da & 45 & 90,0 \\
\hline Khớp & 28 & 56,0 & $\begin{array}{l}\text { Sưng đau } \\
\text { khớp }\end{array}$ & 28 & 56,0 \\
\hline \multirow{4}{*}{$\begin{array}{l}\text { Tiêu } \\
\text { hóa }\end{array}$} & \multirow{4}{*}{34} & \multirow{4}{*}{68,0} & Đau bụng & 32 & 64,0 \\
\hline & & & Nôn máu & 6 & 12,0 \\
\hline & & & $\begin{array}{l}\text { Đi ngoài } \\
\text { phân máu }\end{array}$ & 12 & 24,0 \\
\hline & & & Tiêu chảy & 5 & 10,0 \\
\hline \multirow{3}{*}{ Thận } & \multirow{3}{*}{9} & \multirow{3}{*}{18,0} & $\begin{array}{l}\text { Đái máu } \\
\text { đại thể }\end{array}$ & 6 & 12,0 \\
\hline & & & Phù & 4 & 8,0 \\
\hline & & & $\begin{array}{l}\text { Tăng huyết } \\
\text { áp }\end{array}$ & 6 & 12,0 \\
\hline \multirow{2}{*}{\multicolumn{3}{|c|}{ Triệu chứng khác }} & Sốt & 5 & 10,0 \\
\hline & & & $\begin{array}{l}\text { Sưng nề } \\
\text { bìu }\end{array}$ & 3 & 6,0 \\
\hline
\end{tabular}

Nhận xét: VMMDU ảnh hưởng đến các cơ quan da, tiêu hóa, khớp, thận với tỷ lệ lần lượt là $90,0 \% ; 68,0 \% ; 56,0 \% ; 18,0 \%$. Trong đó triệu chứng gặp nhiều nhất là ban xuất huyết trên da, đau bụng và sưng đau khớp với tỷ lệ lần lượt là: $90,0 \% ; 64,0 \% ; 56,0 \%$.

Bảng 4. Các đặc điểm về xét nghiệm máu ( $\mathrm{n}=50)$

\begin{tabular}{|c|c|c|c|c|}
\hline \multicolumn{2}{|c|}{ Xét nghiệm } & $\mathrm{n}$ & $\%$ & $\begin{array}{l}\text { Giá trị trung } \\
\text { bình }\end{array}$ \\
\hline \multirow{4}{*}{$\begin{array}{l}\text { Công } \\
\text { thức } \\
\text { máu }\end{array}$} & $\begin{array}{l}\text { Giảm } \\
\text { hồng } \\
\text { cầu }\end{array}$ & 1 & 2,0 & \\
\hline & $\begin{array}{l}\text { Giảm } \\
\text { huyết } \\
\text { sắc tố }\end{array}$ & 1 & 2,0 & $130,1 \pm 13,5 \mathrm{~g} / \mathrm{L}$ \\
\hline & $\begin{array}{l}\text { Tăng } \\
\text { bạch } \\
\text { cầu }\end{array}$ & 16 & 32,0 & $15,3 \pm 7,1 \mathrm{G} / \mathrm{L}$ \\
\hline & $\begin{array}{l}\text { Số lượ } \\
\text { TB }\end{array}$ & bạc & cầu & $\begin{array}{l}427,4 \pm 132,2 \\
\text { G/L }\end{array}$ \\
\hline \multirow{4}{*}{$\begin{array}{l}\text { Sinh } \\
\text { hóa } \\
\text { máu }\end{array}$} & $\begin{array}{l}\text { Tăng } \\
\text { ALT }\end{array}$ & 1 & 2,0 & \\
\hline & $\begin{array}{l}\text { Tăng } \\
\text { AST }\end{array}$ & 2 & 4,0 & \\
\hline & $\begin{array}{l}\text { Tăng } \\
\text { ure }\end{array}$ & 4 & 8,0 & \\
\hline & $\begin{array}{l}\text { Tăng } \\
\text { CRP }\end{array}$ & 17 & 34,0 & $17,3 \pm 19,8 \mathrm{mg} / \mathrm{l}$ \\
\hline
\end{tabular}

Nhận xét: tăng CRP và tăng bạch cầu là 2 thay đổi phổ biến nhất trong nghiên cứu này với tỷ lệ lần lượt là $34,0 \%$ và 32,0\%.

Bảng 5. Điều trị viêm mao mạch dị ứng

\begin{tabular}{llll}
\hline Phương pháp điều trị & $\begin{array}{l}\text { Số } \\
\text { lượng } \\
\text { (n) }\end{array}$ & Tỷ lệ (\%) \\
\hline $\begin{array}{l}\text { Không điều trị corticoit } \\
\text { (kháng Histamin) }\end{array}$ & 12 & 24,0 \\
\hline & $\begin{array}{l}\text { Uống } \\
\text { prednisolon }\end{array}$ & 26 & 52,0 \\
\hline & $\begin{array}{l}\text { Truyền } \\
\text { methypredni } \\
\text { solon }\end{array}$ & 9 & 18,0 \\
\cline { 2 - 3 } Điều trị \\
corticoid & $\begin{array}{l}\text { Truyền } \\
\text { methypredni } \\
\text { solon và } \\
\text { thuốc ức chế } \\
\text { miễn dịch }\end{array}$ & 3 & 6,0 \\
\hline Tổng & & 60 & 100,0 \\
\hline
\end{tabular}


Nhận xét: phác đồ điều trị bằng prednisolon được sử dụng nhiều nhất $52,0 \%$ trong điều trị bệnh nhân VMMDƯ ở nghiên cứu này.

Bảng 6. Kết quả điều trị sau 3 tháng theo dõi

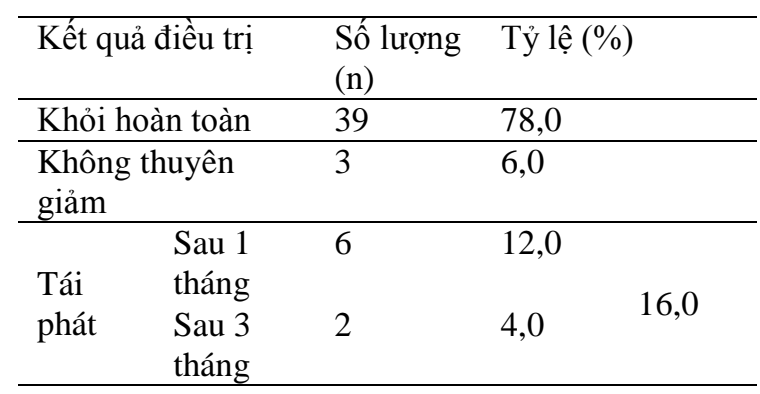

Nhận xét: 78,0\% số bệnh nhân khỏi bệnh hoàn toàn; $16,0 \%$ bệnh nhân tái phát và $6,0 \%$ bệnh nhân vẫn chưa đạt được thuyên giảm trong quá trình điều trị.

\section{Bàn luận}

\section{1. Đặc điểm dịch tễ học, lâm sàng và cận lâm sàng}

Theo kết quả nghiên cứu sự phân bố theo tuổi của bệnh nhân VMMDU' là từ 4 đến 15 tuổi, gặp nhiều nhất ở bệnh nhân từ 6 đến 8 tuổi. Tuối trung bình bị bệnh là $9,1 \pm 3,2$ tuổi. Kết quả này không có sự khác biệt nhiều với kết quả nghiên cứu của Liu và cs $(2015, \mathrm{n}=325)$ có độ tuổi trung bình là $8,4 \pm 2,9$ [3]. Theo kết quả nghiên cứu, bệnh nhân VMMDU' gặp ở cả 2 giới, trong đó trẻ trai gặp nhiều hơn trẻ gái, tỷ lệ trẻ trai/trẻ gái = 1,17:1 không khác biệt với kết quả nghiên cứu của Lê Thị Minh Hương (2013, n=216), Lee (2016, n=212) lần lượt cho tỷ lệ trẻ trai/ trẻ gái là 1,$7 ; 1,23 ; 1,9[4,5]$. Theo quả nghiên cứu trong hình 1 cho thấy bệnh xuất hiện với tỷ lệ cao hơn trong các tháng mùa đông, xuân, thu, hè lần lượt là $38,0 \% ; 28,0 \% ; 20,0 \% ; 14,0 \%$. Tính chất mùa trong bệnh VMMDU có thể là do trẻ em thường bị nhiễm trùng đường hô hấp trong những ngày lạnh đây là một trong những yếu tố khởi phát bệnh VMMDU. Bảng 1 cho thấy $44,0 \%$ bệnh nhân khởi có kèm theo nhiễm trùng trước đó, trong đó chủ yếu liên quan đến nhiễm trùng đường hô hấp trên với $20,0 \%$ và trẻ mắc các bệnh viêm phổi phế quản ở $8,0 \%$, ngoài ra nhiễm khuẩn đường tiết niệu và nhiễm khuẩn đường tiêu hóa cũng gặp ở $8,0 \%$ và $6,0 \%$. Trong nghiên cứu của Liu và cs tỷ lệ bệnh nhân khởi phát bệnh liên quan đến yếu tố nhiễm trùng là $57,2 \%$ và nhiễm trùng đường hô hấp trên cũng là chủ yếu $36,6 \%$ [3]. Các kết quả nghiên cứu trên thế giới đều nhận thấy có mối liên quan giữa các bệnh nhiễm trùng và bệnh, đặc biệt là nhiễm trùng hô hấp trên đển sự khởi phát bệnh. Biểu hiện lâm sàng khi khởi phát bệnh trong Bảng 2 cho thấy triệu chứng lâm sàng bệnh khá đa dạng, trong đó triệu chứng đầu tiên thường gặp nhất là ban xuất huyết trên da đơn thuần, đau bụng đơn thuần, tỷ lệ các triệu chứng lần lượt là $42,0 \%$; $18,0 \% ; 16,0 \%$. Tác giả Lê Thị Minh Hương và cs thấy nổi ban, đau bụng, đau khớp là 3 triệu chứng khởi đầu chính với tỷ lệ $40,0 \% ; 32,0 \%$; $17,0 \%$ [4]. Như vậy, triệu chứng khởi phát đầu tiên gặp nhiều nhất là ban xuất huyết ở da nhưng với tỷ lệ không nhiều $42,0 \%$, điều này dễ dẫn đến trường hợp bỏ sót chuẩn đoán hoặc chuẩn đoán nhầm với các bệnh viêm dạ dày, viêm khớp,... trong giai đoạn đầu. Theo kết quả nghiên cứu trong bảng 3 về các biểu hiện lâm sàng ở giai đoạn toàn phát cho thấy ban da gặp ở hầu hết bệnh nhân $(90,0 \%)$. Tính chất xuât hiện ở vùng thấp của ban có thể liên quan đến dòng máu ở khu vực này chậm hơn nên khả năng tích lũy các phức hợp miễn dịch cao hơn, ngoài ra áp lực cao hơn cũng làm quá trình thoát mạch diễn ra dễ dàng hơn. Ban da mờ dần trong 1 đến 38 ngày và trung bình là $10,8 \pm 8,7$ ngày, biểu hiện ở khớp là sưng khớp và đau khớp gặp 56,0\% và các khớp lớn ở chi dưới (đầu gối, cổ chân). Các triệu chứng chính ở đường tiêu hóa là đau bụng $(64,0 \%)$ với đặc điểm mơ hồ không rõ vị trí đau, bệnh nhân nhận thấy đau xung quanh rốn hoặc có thể lan tỏa toàn bụng. Xuất huyết tiêu hóa cũng gặp ở một tỷ lệ đáng kể (đi ngoài phân máu $24,0 \%$ và nôn máu $12,0 \%$ ), một số bệnh nhân có biểu hiện rối loạn tiêu hóa như đi ngoài phân lỏng ở $10 \%$. Tác giả Lê Thị Minh Hương và cs cũng cho kết quả đau bụng là biểu hiện chính của đường tiêu hóa $60,9 \%$ sau đó đến ỉa máu $21,1 \%$ và nôn máu 9,6\% [4]. Những triệu chứng này được gây ra bởi sự xuất huyết dưới niêm mạc và 
phù nề của thành ruột làm bệnh nhân đau bụng và thường kèm theo cảm giác buồn nôn, nôn và tiêu chảy. Trong nghiên cứu của tôi, nhóm triệu chứng lâm sàng của tổn thương thận chỉ chiếm $18,0 \%$ là thấp so với các nghiên cứu khác là do tổn thương thận ở các nghiên cứu khác.Tổn thương thận trong VMMDU là tổn thương nặng nề và nguy hiểm, đôi khi không biểu hiện ở triệu chứng lâm sàng, mà chúng ta cần làm xét nghiệm nước tiểu để đánh giá tiểu máu vi thể và protein niệu. Đặc biệt tổn thương thận có thể kéo dài đến 6 tháng sau mới biểu hiện, do đó, số bệnh nhân tổn thương thận thực sự có thể còn tăng thêm. Theo nghiên cứu đa trung tâm của Buscatti và cs trong 10 năm trên 296 trẻ mắc VMMDU tại khu vực châu Mỹ - La tinh thấy tổn thương thận xuất hiện $47 \%$, trẻ có tổn thương thận sẽ có tỷ lệ xuất huyết tiêu hóa, tái phát dai dẳng cao hơn hẳn nhóm không có tổn thương thận [6]. Kết quả xét nghiệm cận lâm sàng trong bảng 4 cho thấy thiếu máu gặp ở $2 \%$, nồng độ huyết sắc tố trung bình là $130,1 \pm 13,5 \mathrm{~g} / \mathrm{L}$, trong nghiên cứu của Lê Thị Minh Hương và cộng sự (2013, $\mathrm{n}=261$ ) huyết sắc tố trung bình hồng cầu là $125 \pm 16 \mathrm{~g} / \mathrm{L}$ [4]. Cho thấy VMMDU' ít gặp bệnh nhân thiếu máu mặc dù có tình trạng tổn thương và xuất huyết các mao mạch nhỏ. Tức là mức độ xuất huyết là không nặng nề, bệnh nhân ít khi rơi vào tình trạng thiếu máu. Tăng bạch cầu và tăng CRP là 2 biến đổi chính của bệnh nhân VMMDU. Số lượng bạch cầu trung bình là 15,3 $\pm 7,1 \mathrm{G} / \mathrm{L}$, trong đó số bệnh nhân tăng bạch cầu trên $15 \mathrm{G} / \mathrm{L}$ chiếm tỷ lệ $32,0 \%$. CRP trung bình là 17,3 $\pm 19,8 \mathrm{mg} / \mathrm{l}$ trong đó $34,0 \%$ bệnh nhân tăng CRP $>6 \mathrm{mg} / \mathrm{l}$. Cho thấy sự kết hợp của tình trạng nhiễm trùng với bệnh ở một tỷ lệ tương đối cao. Kết quả của chúng tôi cũng khá tương đồng kết quả nghiên cứu của Lê Thị Minh Hương và cs với số lượng bạch cầu trung bình là $14,7 \pm 7,0 \mathrm{G} / \mathrm{L}$, có $36 \%$ bệnh nhân bạch cầu tăng trên $15 \mathrm{G} / \mathrm{L}$ [4]. Số lượng tiểu cầu trung bình là

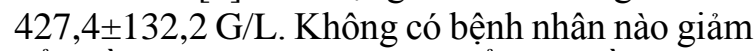
tiểu cầu trong nghiên cứu, thể hiện rằng giảm tiểu cầu không phải là cơ chế bệnh sinh của tình trạng xuất huyết trong bệnh VMMDU'. Một số ít bệnh nhân có tăng men gan (4\%), tăng ure (8\%). Nhìn chung y văn ghi nhận thấy các thay đồi xét nhiệm máu ít có giá trị chẩn đoan bệnh nhân mắc VMMDU' mà chủ yếu để loại trừ một số trường hợp mà lâm sàng chưa rõ ràng.

\section{2. Đánh giá kết quả điều trị}

Thống kê các thuốc điều trị trong Bảng 5 cho thấy số bệnh nhân không cần điều trị bằng corticoit chiếm $24,0 \%$. Nhóm bệnh nhân này thường chỉ được kê đơn thuốc kháng histamin, điều trị triệu chứng. Hiện tại chưa có khuyến cáo thống nhất cao trong việc điều trị VMMDU bằng corticoid một cách hệ thống do các tác giả cho rằng ngăn ngừa được tổn thương thận hoặc biến chứng ở đường tiêu hóa, cũng không làm thay đổi tỷ lệ tái phát. Tuy nhiên, corticoid có vai trò trong việc kiểm soát triệu chứng của bệnh, đặc biệt trong điều trị đau bụng, đau khớp và ban xuất huyết. Trong nghiên cứu của chúng tôi, có $76 \%$ trẻ được điều trị bằng corticoit, trong đó uống prednisolon liều $1 \mathrm{mg} / \mathrm{kg} / \mathrm{ngày}$ được áp dụng ở $52,0 \%$ bệnh nhân. Nghiên cứu của Lee và cs ở Khoa Nhi, Bệnh viện Sanggye, Hàn Quốc cũng cho phần lớn điều trị VMMDU bằng corticoid $(88,7 \%)$, trong đó $44,3 \%$ là corticoid liều thấp với liều trung bình $1,02 \mathrm{mg} / \mathrm{kg} /$ ngày và $8,9 \%$ là corticoid liều cao với liều trung bình là $2,01 \mathrm{mg} / \mathrm{kg} /$ ngày [5]. Có 2 bệnh nhân có hội chứng thận hư và 1 bệnh nhân protein niệu dai dẳng trong nghiên cứu đang phải sử dụng phác đồ truyền methyprednisolon kết hợp với thuốc ức chế miễn dịch hàng tháng. Về kết quả điều trị trong bảng 6 cho thấy tiên lượng chung của VMMDƯ trong nghiên cứu của chúng tôi là khá tốt. Tuy nhiên đã ghi nhận 3 trường hợp vẫn chưa đạt được sự thuyên giảm khi kết thúc nghiên cứu, các trường hợp này đang phải sử dụng phác đồ điều trị kết hợp thuốc ức chế miễn dịch hàng tháng và đều có liên quan đến tổn thương thận dai dẳng. Theo kết quả nghiên cứu của Delbet và cs theo dõi 92 trẻ bị VMMDU' có tổn thương thận trong vòng 3 năm thấy $12 \%$ trẻ không đạt được thuyên giảm, chỉ có $75 \%$ trẻ đạt được thuyên giảm hoàn toàn. Như vậy nếu trẻ bị tổn thương thận sẽ tái phát nhiều hơn và khó điều trị hơn [7]. 


\section{Kết luận}

- Tuổi mắc hay gặp ở trẻ trong độ tuổi đi học, trẻ trai găp nhiều hơn trẻ gái. Thời gian xuất hiện bệnh thường vào mùa đông và mùa xuân (từ tháng 11 đến tháng 3). Bệnh khởi phát có liên quan đến yếu tố nhiễm trùng trước đó; Triệu chứng khởi phát thường gặp nhất là ban da, đau bụng, trong đó ban xuất huyết đối xứng dưới da gặp nhiều nhất (trên 90\%).

- Tổn thương thận không cao, thường âm thầm, khó phát hiện, có thể từ không triệu chứng đến biểu hiện của viêm cầu thận cấp hay hội chứng thận hư.

- Liệu pháp sử dụng thuốc prednisolon uống liều $1 \mathrm{mg} / \mathrm{kg} /$ ngày là phương pháp điều trị phổ biến. Bệnh nhân có hội chứng thận hư tái phát nhiều lần cần điều trị liệu pháp ức chế miễn dịch đa đích. Đa số bệnh nhân khỏi bệnh hoàn toàn; $6,0 \%$ chưa đạt được thuyên giảm và $16,0 \%$ bệnh nhân tái phát sau 3 tháng.

\section{Lời cảm ơn}

Nhóm nghiên cứu xin gửi cảm ơn đến nhóm Nghiên cứu Đề tài Khoa học và Công nghệ năm cấp cơ sở 2018 tại Khoa Nhi, Bệnh viện Bạch Mai, bệnh nhân và người nhà các đối tượng nghiên cứu đã giúp đỡ chúng tôi hoàn thành nghiên cứu này.

\section{Tài liệu tham khảo}

[1] EULAR/PRINTO/PRES, Citeria for HenochSchönlein purpura, childhood polyarteritis nodosa, childhood Wegener granulomatosis and childhood Takayasu arteritis: Ankara 2008, Part II: Final classification criteria, AnnRheum Dis 69 (2010) 798-806.

[2] Seza Ozen, Stephen D. Marks, Paul Brogan et al, European consensus-based recommendations for diagnosis and treatment of immunoglobulin A vasculitis-the SHARE initiative, Rheumatology, 58(9) (2019) 1607-1616.

[3] L.J. Liu, J. Yu and Y.N. Li, Clinical characteristics of Henoch-Schonlein purpura in children, Zhongguo dang dai er ke za zhi. Chinese journal of contemporary pediatrics 17(10) (2015) 1079-1083.

[4] Le Thi Minh Huong, Thuc Thanh Huyen, study about characteristics of clinical and paraclinical manifestations of HSP in children in National Pedicatrics of hospital, Journal of Practical Medicine 874(6) (2013) 91-94 (in Vietnamese).

[5] Y.H. Lee, Y.B. Kim, J.W. Koo et al, HenochSchonlein Purpura in children hospitalized at a tertiary hospital during 2004-2015 in Korea: epidemiology and clinical management,Pediatric gastroenterology, hepatology \& nutrition 19(3) (2016) 175-185.

[6] I.M. Buscatti, B.B. Casella, N.E. Aikawa et al, Henoch-Schönlein purpura nephritis: initial risk factors and outcomes in a Latin American tertiary center. Clin Rheumatol 37(5) (2018) 1319-1324.

[7] J.D. Delbet, J. Hogan, B. Aoun et al, Clinical outcomes in children with Henoch-Schönlein purpura nephritis without crescents. Pediatr Nephrol 32(7) (2017) 1193-1199. 